УДК $821.111,329.23$

DOI 10.22455/2541-7894-2019-7-414-439

\title{
Родион БЕЛЬКОВИЧ
}

\section{ЭЗРА ПАУНД И РЕСПУБЛИКАНСКАЯ ТРАДИЦИЯ}

Аннотация: Основной корпус литературы, посвященной политическим воззрениям Эзры Паунда, сосредоточен вокруг проблематики фашизма и антисемитизма. Настоящая статья смещает фокус исследования на значительно менее разработанный вопрос о влиянии республиканского наследия на характерный стиль мышления Э. Паунда о политике. Ключевое значение в связи с этим имеет текст «Джефферсон и/или Муссолини», содержащий наиболее полное и последовательное изложение взглядов поэта на власть и ее соотношение с экономикой и культурой. Проводя прямые параллели между лидерами двух революций, Эзра Паунд позволяет нам выявить те элементы американской политической традиции, идентификация с которыми и заставила его поддержать страны Оси во Второй мировой войне. Республиканизм оказывается той парадигмой, которая позволяет охватить и объяснить практически весь спектр взглядов поэта, на первый взгляд кажущихся противоречивыми. В этом контексте Эзра Паунд оказывается не эксцентричным художником, чье обращение к радикальной политике было продиктовано особенностями творческой натуры, и не провинциальным шовинистом, но наследником и выразителем традиционной системы ценностей, насильственно вытесненной в новейшее время на периферию политической жизни США.

Ключевые слова: Эзра Паунд, республиканизм, фашизм, Томас Джефферсон, Бенито Муссолини.

(c) 2019 Родион Юрьевич Белькович (кандидат юридических наук, доцент; Национальный исследовательский университет «Высшая школа экономики», Москва, Россия) rbelkovich@hse.ru 
UDC 821.111, 329.23

DOI 10.22455/2541-7894-2019-7-414-439

\section{Rodion BELKOVICH}

\section{EZRA POUND AND THE REPUBLICAN TRADITION}

Abstract: The topics of fascism and anti-Semitism constitute the core research problems of contemporary scholarship on the political ideas of Ezra Pound. This article shifts the research focus to the topic, which has attracted much less academic attention, namely - the influence of republican intellectual heritage on the peculiar style of Ezra Pound's political thinking. The most crucial text in this regard is Jefferson and/or Mussolini, which contains the most consistent and extensive expression of poet's views on authority and its relations to economics and culture. By drawing the direct parallels between the two revolutionary leaders, Pound provides us with an opportunity to unveil the elements of American political tradition, the identification with which made it possible for him to support the Axis powers in the course of World War II. The republicanism seems to be a paradigm capable of embodiment and explaining the whole range of seemingly contradictory poet's ideas. Considered from this perspective, Pound does not anymore appear to be an eccentric artist, whose turn to radical politics is only a continuation of his poetic character, nor is he a provincial chauvinist, but reveals himself as an heir and a representative of the traditional system of values, which has been violently relocated to the margins of political life in the USA.

Keywords: Ezra Pound, republicanism, fascism, Thomas Jefferson, Benito Mussolini.

(C) 2019 Rodion Yu. Belkovich ( $\mathrm{PhD}$ in Law, Associate Professor; National Research University Higher School of Economics, Moscow, Russia) rbelkovich@hse.ru 
Как отмечал Форрест МакДональд, на территории Северной Америки как до Революции, так и после нее существовало два противостоящих друг другу политических лагеря, которые вынуждены были объединиться во время борьбы за независимость, чтобы потом вступить в борьбу уже друг с другом: «...две группы, одна, яростно отстаивавшая республиканизм, и только во вторую очередь - нацию, и другая, яростно отстаивавшая нацию, и только во вторую очередь - республиканизм» ${ }^{1}$. В период дискуссий о Конституции эти группы получили наименования анти-федералистов (выступавших за сохранение логики Статей Конфедерации, то есть за децентрализацию и «локальный контроль над локальными вопросами» по выражению Паунда) $)^{2}$ и федералистов (стремившихся воплотить в США европейские по своему характеру практики сильного национального государства). Однако речь сейчас идет не о конфликте двух конкретных субъектов realpolitik, но о противостоянии принципиально различных мировоззрений, носители которых на протяжении американской истории могли именоваться по-разному. Суть этого противостояния и место в нем Эзры Паунда могут быть поняты только в контексте истории развития политических идей в Новом Свете и заимствования американскими авторами концептов, рожденных в Европе.

Возникшая в среде римских авторов конца дохристианской эры, вновь открытая флорентийскими мыслителями раннего нового времени и принесенная в Великобританию в начале XVII в. традиция республиканизма определила критическую повестку оппозиционно настроенных политиков, философов и публицистов этой эпохи ${ }^{3}$. Именно на языке республиканизма, который стал к середине XVIII в. устойчивой частью английского самосознания, американские колонисты постепенно начали говорить о независимости ${ }^{4}$. Переселенцы считали себя самой

1 McDonald, F. The Presidency of Thomas Jefferson. Lawrence, KS: University Press of Kansas, 1976: 30.

2 Об этом см. напр. Cornell, S. The Other Founders. Anti-Federalism and the Dissenting Tradition in America, 1788-1828. Chapel Hill, NC: University of North Carolina Press, 1999. См. в канто XLVI: «...конечно, не бывает никаких местных свобод / без местного контроля над покупательной способностью». Паунд Э. Кантос. СПб.: Наука, 2018. С. 596.

3 О рецепции республиканизма см. напр. Pocock, J.G.A. The Machiavellian Moment. Princeton, NJ: Princeton University Press, 1975; Robbins, C. The EighteenthCentury Commonwealthman. New York: Atheneum, 1968.

4 Франклин писал, что даже если колонисты и ошибались по поводу своих прав, вытекавших из английской Конституции, это ошибочное мнение привили им 
здоровой частью английской нации - частью, не погрязшей в роскоши и праздности 5 . Они полагали, что Америка должна стать спасением для Англии, население которой было уже не в силах сопротивляться посягательствам власти на свободу. Джон Дикинсон писал, что колонистов «следует признать виновными в измене нашему суверену и величеству (majesty) народа Англии», если они не будут противостоять тирании, развернувшейся в Великобритании. «Англия должна быть спасена в Америке», - утверждал он ${ }^{6}$.

Трудно представить себе фигуру в XX в., в большей степени воплотившую в своей жизни это мироощущение республиканцев XVIII в., чем Эзра Паунд. Американский интеллектуал, нашедший себе пристанище на другом континенте, но осознанно и принципиально сохранявший связь со своей исторической Родиной, Паунд инверсивно воспроизвел логику своих англосаксонских предков - только в новом контексте спасать необходимо было уже Америку ${ }^{7}$. И совершенно логичным в этом смысле был выбор Италии, даже географически отсылавший к республиканской традиции, гибнущей в Соединенных Штатах под напором финансового капитала при полном попустительстве народных масс и интеллигенции ${ }^{8}$. Применительно к ситуации Паунда современник мог вспомнить замечание Марка Туллия Цицерона о том, что в условиях разложения республики принципиальному человеку

авторы из самой Англии. Colbourn, Т. The Lamp of Experience: Whig History and the Intellectual Origins of the American Revolution. Chapel Hill, NC: University of North Carolina Press, 1965: 133.

5 Важно отметить, что колонисты считали себя англичанами не в меньшей степени, чем сами жители британских островов: «наши потомки получат от нас ту же свободу, какую мы получили от своих предков». Selected Political Essays of James Wilson. New York: Alfred Knopf, 1930: 50.

6 Dickinson, J. An Essay on the Constitutional Power of Great-Britain over the Colonies in America. Philadelphia, PA: W. Tomas Bradford, 1774: 62.

7 Интерес Паунда к Американской Революции не вызывает сомнений. Так, например, он отсылает в «Кантос» (XXXII, XXXIII, L) читателя к известному письму Джона Адамса Томасу Джефферсону, где тот подчеркивает, что война «... не была частью революции; она была лишь ее эффектом и следствием. Революция свершилась в умах людей». The Works of John Adams. Vol. X. Boston, MA: Little, Brown and Company, 1856: 172. Ср. Паунд Э. Кантос. С. 148-149, 151, 229. Именно над такой трансформацией старательно работал Паунд во время своего пребывания в Рапалло.

8 «Наследие Джефферсона, Квинси Адамса, старого Джона Адамса, Джексона, Ван Бюрена обитает ЗДЕСЬ, СЕЙЧАС на итальянском полуострове в начале второй фашистской декады, а не в Массачусетсе или Делавэре». Pound, Е. Jefferson and/or Mussolini. London: Stanley Nott Ltd., 1935: 12. 
иногда приходится оказаться на чужбине («он как человек свободолюбивый и храбрый отказался от отечества; он был принят тарквинянами в число их граждан и поселился в этой городской общине» ${ }^{9}$, - этот пассаж вполне может описывать и ситуацию поэта-модерниста). Фактически определяя Родину не случайностью рождения, но культурной идентификацией, Паунд вопрошал: «Вызов Муссолини Америке состоит попросту в следующем: ВОПЛОЩАЮТСЯ ли на самом деле в Америке этого десятилетия живые идеи Дюеефферсона, Куинси Адамса, Ван Бюрена и кого-либо ещзе со страниц цуенной части нашей истории в той мере, в которой они воплощуаются в Италии при ДУЧЕ?» ${ }^{10}$.

Таким образом, поэтико-политическая деятельность Паунда, квинтэссенцией которой, во многом, стала работа «Джефферсон и/или Муссолини» ${ }^{11}$, лежит вовсе не в плоскости противостояния фашизма и либерализма, пропаганды антисемитизма или сомнительных экономических теорий. Она представляет собой попытку реинтерпретации (Make it new!) республиканской традиции в новых исторических условиях ${ }^{12}$. Паунд, с одной стороны, стремился обновить эту традицию, адаптировав ее к современности, а с другой - унаследовал многие характерные ее «англосаксонские» черты, определившие, в частности, и особенности языка и манеры ее изложения. Ричард Хофстедтер перечислял такие особенности этой традиции, свойственные для политической культуры США: «Идея золотого века; концепция естественной гармонии; дуалистичное видение социальных противостояний; конспи-

9 Цииерон. Диалоги: О государстве; О законах. М.: Наука, 1966. С. 43.

10 Pound, E. Jefferson and/or Mussolini: 104.

11 Написана в период между 9 и 22 февраля 1933 года, после встречи Паунда с дуче 30 января. Surette, L. Dreams of a Totalitarian Utopia: Literary Modernism and Politics. London: McGill-Queen's University Press, 2011: 221.

12 Следует заметить, что обвинение Паунда в измене отсылает нас не только к конфликту колонистов с Британией в XVIII веке, но и к другому важнейшему для американской истории событию - войне Севера и Юга. Логика борьбы Юга за независимость во многом воспроизводит как риторику 1776 года, с одной стороны, так и критику Паундом финансистов восточного побережья - с другой. Паунд указывал на то, что его интерес к правам штатов возник уже во время обучения в университете в 1901 или 1902 году. См. Marsh, A. John Kasper and Ezra Pound. London; New York: Bloomsbury Academic, 2015: 13. Кроме того, о «предпочтениях» в контексте войны между штатами свидетельствует и замечание Паунда о том, что «Южные Штаты, вероятно, имели “право” на сецессию, если о “правах” можно судить пописьменным источникам и духу Статей Конфедерации, предшествовавшим Американской Конституции». Pound, E. Pavannes \& Divagations. New York: New Directions Publishing, 1958: 30. 
рологическая интерпретация истории; и доктрина первостепенного значения денег». Утерянным раем была «республиканская Америка первых лет девятнадцатого века, где ... фермера ждало изобилие» ${ }^{13}$. Bсе это в полной мере применимо к стилю Паунда, являющемуся не аберрацией восприимчивой поэтической натуры, но частным случаем конкретной социально-политической парадигмы мышления радикального республиканизма.

Конспирологическая интерпретация истории имела в рамках этой парадигмы несколько слоев. Прежде всего - идею избранности американского народа. В качестве одного из обоснований этой избранности выступала политическая история англосаксов, ведущая начало (отчасти мифологически) от Англии донормандского периода. Колонисты отождествляли себя с потомками свободолюбивых германских племен, описанных Тацитом. Историки-республиканцы описывали политические институты этих племен как крайне демократичные, основанные на принципах юридического равенства, и предполагавшие участие большей части населения в отправлении власти. Эту логику социальной организации германцы перенесли с собой и на британские острова, где она сохранялась до введения нормандскими завоевателями феодальных отношений, чуждых англосаксам. Таким образом, социально-политический конфликт в сознании американских республиканцев всегда имел определенный этнический оттенок. Вся последующая история Англии оказывалась чередой попыток отвоевать отнятые чужеземными захватчиками древние свободы. В частности, Великая хартия вольностей объявлялась одним из памятников этого многовекового сопротивления пришлым завоевателям. Однако политический маятник непрерывно качался, подталкиваемый, с одной стороны, героическими борцами против тирании, а с другой - развращенными представителями правящих кругов, стремившимися ценой любых злоупотреблений сохранять контроль над населением и усиливать эксплуатацию. Даже колонизация пуританами Нового Света рассматрива-

13 Hofstadter, R. The Age of Reform: From Bryan to F.D.R. New York: Vintage Books, 1955: 62. Следует подчеркнуть, что для Хофстедтера, эти характеристики имеют заведомо отрицательные коннотации и ассоциируются y него с «параноидальным стилем» американской политической культуры. В этом отношении он наследует традиции политического мышления Александра Гамильтона и других федералистов, которые, по словам Паунда, «занимались предательством людей, предавая их честно, искренне, с глубокой убежденностью в том, что их долг состоял в преображении тринадцати колоний в максимально точную имитацию Британии». Pound, E. Jefferson and/or Mussolini: 14. 
лась республиканцами как продолжение этой борьбы с разлагающейся властью, ассоциировавшейся с католичеством и не очищенной от его элементов официальной Церковью Англии. Однако тирания, высосавшая все соки из населения британских островов, протягивала свои щупальца и за океан, пытаясь ввести налоги, не обеспечив при этом представительство американцев в английском парламенте. Именно опираясь на идею о древних правах англосаксов (прежде всего - на невозможность принудительного налогообложения) колонисты начали свое вооруженное сопротивление короне. Томас Джефферсон настолько был впечатлен историей англосаксонских предков, что даже свой тезис о необходимости окончательного отделения церкви от государства он подкреплял почерпнутым из исторических работ вигов мнением о том, что священство было чуждым для англосаксов социальным слоем, который был им навязан после завоевания Вильгельмом. Паунд, в свою очередь, отдает должное «ранним фашистским манифестам», носившим антиклерикальный характер. «Христианское разложение не смогло заразить итальянца, он относится к нему спокойно, с опорой на средиземноморское здравомыслие», - так поэт воспроизводит логику локального сопротивления в новых условиях ${ }^{14}$.

Германские предки были настолько важным символическим аттрактором для Джефферсона, что он предложил Виргинии проект государственной печати, содержавший изображения саксонских вождей Хенгиста и Хорсы. Неудивительно, что германское прошлое оказывается принципиальным и для Паунда, который уделяет внимание древним королям в канто CV, а в кантос CVII-CIX подробно рассматривает историю становления традиции свободы у англосаксов, от Великой хартии вольностей до сэра Эдварда Коука. Там же Паунд ведет речь и о кентерберийском архиепископе Ансельме XI-XII веков: «Вы могли бы, черт возьми, поблагодарить Св. Ансельма, поскольку все ваши свободы рождены задолго до “Мэгги Картер”, как ее называли в школах права в Америке» ${ }^{15}$. Все это - свидетельства характерно республиканского интереса поэта к праву и закону как способам борьбы с тиранией. В одном из своих писем он прямо подчеркивает необходимость использовать «закон, даже если тираны этого не делают. Теорию права, букву закона, пока она не отменена в рамках конституционного

14 Pound, E. Jefferson and/or Mussolini: 31.

15 Цит. по Terrell, C.F. A Companion to The Cantos of Ezra Pound. Vol. II. Berkeley, CA: University of California Press, 1984: 683. 
процесса ${ }^{16}$. В этом контексте ясным становится замечание Паунда по поводу Муссолини: «Помести его в Англию, и он указал бы на ее корни в Витенагемоте...» ${ }^{17}$. Однако Муссолини был не в Англии, он был в Италии. И потому он должен был искать иную, укорененную в итальянской культуре форму республиканского политического проекта для Италии $\mathrm{XX}$ в. Слепое копирование исторических или культурных образцов не приведет к достижению общего блага: «...Италия это не Россия, а Америка - не Италия, а Россия - не Америка и т.д., и я не “рекомендую” Америке пытаться быть Россией или Италией...»" ${ }^{18}$ Тем не менее, по мнению Паунда, и в Англии, и в Италии, и в США на протяжении веков идет одна и та же принципиальная борьба между силами здоровья и увядания, изобилия и нехватки.

В этом отношении Паунд наследует апокалиптическое мироощущение ранних пуритан ${ }^{19}$. История для них оказывалась ареной борьбы сил добра и зла, где Америка сражалась со слугами дьявола. В таких условиях людям необходимо быть всегда начеку, так как самые эффективные приемы темных сил связаны со скрытым внедрением порока в души людей. И именно конкретные люди становились для колонистов центрами влияния (положительного или отрицательного), изменяющими весь политический ландшафт. Другими словами, «в этой культуре вопрос по поводу событий звучал не “как они произошли?”, а “кто стал их причиной?” ${ }^{20}$. Эта концентрация внимания на отдельных личностях была питательной основой для конспирологической трактовки событий ${ }^{21}$. Антисемитизм Паунда всего лишь воспроизводит эту идею персональной ответственности конкретных лиц за разложение социума

16 Ezra Pound's Chinese Friends. Oxford: Oxford University Press, 2008: 194.

17 Pound, E. Jefferson and/or Mussolini: v. Паунд прямо указывает на историчность мышления Муссолини: «Одним из показателей глубины Дуче является его непрестанная аккуратная критика всего "anti-storico", всего что противостоит историческому процессу». Ibid.

18 Ibid.: 40.

19 «...пуританизма или протестантизма, или проклятого Кальвина и Лютера, и всех этих прочих зануд, которые сидят, хотим мы этого или нет, у нас, американцев, на плечах». Ibid.: 44.

20 Wood, G. The Radicalism of the American Revolution. New York: Vintage Books, 1991: 61 .

21 Вуд называет «Письма Катона» типичным примером литературы «параноидальных вигов». См. Wood, G. "Conspiracy and the Paranoid Style: Causality and Deceit in the Eighteenth Century." The William and Mary Quarterly 39:3 (July, 1982): 401-444. 
в целом. В переписке с Рольфом Хоффманом, который отмечал успехи в деле экстрадиции евреев из Рейха в Америку, Паунд сокрушался: «Как АМЕРИКАНЕЦ (и насколько!) я не ХОЧУ еще больше проклятых богом КРУПНЫХ евреев в моей стране». Гораздо легче нейтрализовать «тридцать или три сотни человек, стремившихся убить Европу» пока они все еще остаются в Европе, чем допустить их растворение вместе с их капиталами на огромной территории Нового Света, где они смогут влиять на общественное мнение через контроль над газетами и издательствами ${ }^{22}$. Опасность представляют не евреи как таковые, а конкретные носители перверсивных ценностей ${ }^{23}$. Их еврейство для Паунда - статистический факт, а не содержание проблемы. Еврейская культура и религия являются факторами, исторически определяющими эту статистическую диспропорцию. В силу сложившихся особенностей мышления, с его точки зрения, евреи не способны создать политический порядок европейского типа. Им свойственны лишь системы эксплуатации, направленные на то, чтобы «взымать деньги с населения в интересах коэнов и левитов» ${ }^{24}$. Во время допроса Паунд заявил: «Я не антисемит, и я различаю еврейского ростовщика и еврея, который зарабатывает на жизнь честным трудом» ${ }^{25}$. Борьбу следует вести не с евреями, но с их практиками. Паунд пишет: «...Все, что Дуг имеет в виду, хотя, конечно, в МЕНЬШЕЙ степени, чем я, это то, что мы ПРОТИВ ростовщиков ДАЖЕ если эти ублюдки - арийцы» ${ }^{26}$. Итак, речь идет о конкретных лицах, которые могут быть подвергнуты и физическому уничтожению в силу того вреда, который они причиняют не только европейской цивилизации, но и самим евреям, находящимся у них в зависимости. В частности, в 1934 году Паунд предлагал «Серебряным

22 Marsh, A. John Kasper and Ezra Pound: 83. В письме к Оливии Россетти Агрести Паунд критикует «еврейскую монополию на книготорговлю» и пишет: «...проклятый гой слишком легко позволяет жиду использовать печатный станок и манипулировать историей для предотвращения передачи жизненно важных фактов». I Cease Not to Yowl: Ezra Pound's Letters to Olivia Rossetti Agresti. Urbana, IL: University of Illinois Press, 1998: 170.

23 Канто XCVII: те «у кого был закон, но не принципы». Паунд Э. Кантос. C. 615 .

24 Паунд пишет об этом в письме, посвященном извращенной форме религии иудеев и католиков: «вопль о честности против/ ватиканской лжи». I Cease Not to Yowl: Ezra Pound's Letters to Olivia Rossetti Agresti: 40-41.

25 Feldman, M. Ezra Pound's Fascist Propaganda, 1935-45. Basingstoke: Palgrave Macmillan, 2013: 5.

26 Marsh, A. John Kasper and Ezra Pound: 79. 
рубашкам», праворадикальной организации Уильяма Пелли, составить список из 15-20 лиц, которых необходимо будет убить в случае, если они будут способствовать развязыванию очередной мировой войны. Паунд и сам указывал на нескольких кандидатов для этого списка в США, а что касается Англии, то ее жители «такие порядочные и тихие куски дерьма, что они никогда не убьют еврея, которого посвятили в рыцари, а уж тем более - когда сделали из него ЛЛЛорда» ${ }^{27}$.

Случай Паунда совершенно не выбивается из логики традиционной американской политической культуры. Как отмечает Бернард Бейлин, еще задолго до того, как имели место какие-либо серьезные политические столкновения колонистов с метрополией в XVIII в., в колониях широкое распространение получили различные теории заговора, общее содержание которых сводилось к представлению о том, что в рамках Британской империи существует масштабный план окончательного подавления свобод населения. Джон Адамс заявлял в середине XVIII в.: «По-видимому, приводится в действие полноценный план порабощения всей Америки» ${ }^{28}$. Первое и второе формальные обращения Континентального конгресса к народу Великобритании содержали указание на этот план порабощения со стороны британского правительства и рассматривали вооруженное восстание как последний способ заставить короля покончить с тиранией собственных вельмож. Собственно говоря, сердцевину Декларации независимости составляет именно перечисление элементов заговора. Бейлин указывает на то, что внушительный массив исторических экскурсов в революцию, изданный поколением ее участников, имел в качестве основного принципа интерпретации событий именно теорию заговора. Более того, это объяснение перекочевало и в исторические работы следующих поколений. Тезис о заговоре из риторического приема постепенно превратился в неотъемлемую часть исторического нарратива о Революции и вошел в историческое сознание населения США ${ }^{29}$.

Совершенно неудивительно, что и политический стиль Паунда приобретает ровно те же самые черты - история объявляется им полем непрерывной войны двух сил, которые в целом можно обозначить как силы жизни (избытка, плодородия, здоровья, и т.д.) и смерти (нехват-

27 Ibid.: 76.

28 Цит. по Бейлин Б. Идеологические истоки Американской революции. М.: Новое издательство, 2010. С. 268.

29 Там же. С. 78-79, 103-104. 
ки, импотенции, разложения, и т.д.) ${ }^{30}$. Выбор этой пары антагонистов и фиксация Паунда на проблеме ростовщичества, финансов и банковского капитала, заставившая многих даже сомневаться в психическом здоровье поэта, оказывается абсолютно объяснимой в рамках американской политической традиции. Одиозность повестки Паунда - лишь следствие постепенного вытеснения такого стиля мышления на периферию политической жизни в самих Штатах. В Италии Паунд попытался законсервировать республиканскую политическую традицию, найдя для нее новый язык - язык фашизма - однако содержание этой традиции в действительности осталось сугубо американским. Последующее военное поражение Италии (и стран Оси в целом) парадоксальным образом способствовало внутриполитической победе альтернативного (либерально-этатистского) языка в Соединенных Штатах.

Тем не менее, именно во все еще глубоко аграрной Италии в 30-е гг. Паунд обнаруживает (а во многом, безусловно, выдумывает) черты того идиллического республиканского образа социума, восстановления которого желали последователи Джефферсона - «где жизнь была деревенской, взаимоотношения личными, джентри правили в роли естественной аристократии, основная масса населения состояла из честных йоменов, торговля и ремесла существовали только для обслуживания сельского хозяйства, постоянные армии и особые монополии, как и фиктивное богатство на бумаге были неизвестны, а государство было ограничено - ограничено по сути пассивной функцией беспристрастного арбитра и защитника сложившегося социального порядка, а кроме того - неписанной, но нерушимой Конституцией» ${ }^{31}$. Этот «пасторальный идеал неизменно использовался для объяснения самой сути Америки с эпохи ее открытия» и никогда не утрачивал своего влияния на умы и сердца ${ }^{32}$. Джефферсон писал: «Те, кто трудится на земле - избранники Бога, - если у него вообще есть избранники, - души которых он сделал хранилищем главной и истинной добродетели. Это -

30 Ровно в этих же терминах здоровья и разложения рассуждали и памфлетистыреспубликанцы XVII-XVIII вв. После своего ареста Паунд заявил: «Я выступал не по поводу этой войны, но против системы, порождающей одну войну за другой...». Таким образом, речь для него шла о глобальном противостоянии, которое в разные эпохи лишь обрастает конкретикой. Redman, T. Ezra Pound and Italian Fascism. Cambridge: Cambridge University Press, 1991: 227.

31 McDonald, F. The Presidency of Thomas Jefferson: 161-162.

32 Marx, L. The Machine in the Garden: Technology and the Pastoral Ideal in America. New York: Oxford University Press, 1967: 3. 
средоточие, в котором Бог сохраняет горящим тот священный огонь, который иначе мог бы исчезнуть с лица земли. Ни одного примера разложения нравственности нельзя найти у людей, обрабатывающих землю, - ни у одного народа, ни в какие времена. Этой печатью разложения отмечены те, кто не надеясь на небо, на свою собственную землю и свой труд, как это делает, чтобы добыть свое пропитание земледелец, зависит в своем существовании от случайностей и каприза покупателей. Зависимость порождает раболепие и продажность, душит добродетель в зародыше и создает удобные орудия для осуществления честолюбивых замыслов. Случайные обстоятельства, возможно, иногда замедляли естественный прогресс и развитие ремесел, но, вообще говоря, в любом государстве соотношение численности земледельцев и всех других классов населения - это соотношение его здоровых и нездоровых частей, которое является довольно точным барометром для измерения степени его разложения. Поэтому раз у нас есть земля, которую можно обрабатывать, пусть нам никогда не захочется, чтобы наши граждане становились к станку и садились за прялку» ${ }^{33}$.

В экономическом отношении Джефферсон был сторонником французских физиократов, полагавших, что источником всякого благосостояния является земля ${ }^{34}$. Однако корни его воззрений лежат гораздо глубже. Уже древнеримская республиканская литература превозносила земледельца и его взаимоотношения с землей. Цицерон пишет: «Перехожу теперь к наслаждениям от земледелия, доставляющим мне необычайную радость. Им никакая старость не препятствует, и они, как мне кажется, наиболее соответствуют образу жизни мудреца. Ведь сельские хозяева имеют дело с землей, которая никогда не противится их власти и никогда не возвращает того, что получила, не давая прибыли, иногда малой, а чаще более значительной. Впрочем, лично меня радует не только урожай, но и природная сила самой земли» ${ }^{35}$. Отношения между человеком и землей, порождающие средства к существованию, принципиально отличаются от способа получения прибыли, доступного банкиру, финансисту, ростовщику. Кревекер в «Письмах американского фермера», изображая взаимоотношения труженика с землей, преподносит их в крайне интимном, чувственном виде, указывая на землю

33 Джерфферсон Т. Заметки о штате Виргиния. Л.: Наука, 1990. С. 232.

34 Fox-Genovese, E. The Origins of Physiocracy. Ithaca and London: Cornell University Press, 1976: 11.

35 Цицерон. О старости. О дружбе. Об обязанностях. М.: Наука, 1974: 20. 
как бесконечный источник удовольствия и избытка, которыми земля награждает возделывающего ее фермера. Земля преподносит ему «не товары на продажу», но «дары для потребления и наслаждения» ${ }^{36}$. Поразительно, что самые первые строки трактата Марка Порция Катона «Земледелие», древнейшего дошедшего до нас памятника римской прозы, посвящены именно противопоставлению благородства земледельца и ничтожности ростовщика: «Иногда стоило бы дохода ради заняться торговлей, не будь это так опасно, а то и отдавать деньги в рост, будь только это почетно. А предками нашими так принято и так в законах уложено, чтобы вора присуждать ко взысканию вдвое, а ростовщика ко взысканию вчетверо. По этому можно судить, насколько ростовщика считали они худшим гражданином против вора. ... А из земледельцев выходят самые верные люди и самые стойкие солдаты. И доход этот самый чистый, самый верный и вовсе не вызывает зависти, и люди, которые на этом деле заняты, злого не умышляют нисколько» ${ }^{37}$. Это традиционное презрение к торговле и финансовым махинациям и восхваление землевладельца, «чье рождение, состояние и интеллект возвышали его до независимости» было особенно характерно для культуры американского Юга, к которой принадлежал и Джефферсон ${ }^{38}$. Частью этой традиции был и Паунд, относивший поэтов, художников, скульпторов к числу производителей наравне с фермерами и ремесленниками. Только они «создают благосостояние; остальные его распределяют и потребляют» ${ }^{39}$. Сама поэзия должна была для Паунда стать воплощением республиканских ценностей - избавленная от поверхностной роскоши прилагательных, она могла приблизиться к высоким образцам традиционной европейской культуры, цивилизации, «основанной на Гомере, цивилизации, а не просто раздутой империи» ${ }^{40}$.

36 Marsh, A. Money and Modernity: Pound, Williams, and the Spirit of Jefferson. Tuscaloosa, AL: The University of Alabama Press, 1998: 37.

37 Катон М.П. Земледелие. М.-Л.: Издательство Академии Наук СССР, 1950. C. 7 .

38 Fox-Genovese, E., Genovese, E. The Mind of the Master Class: History and Faith in the Southern Slaveholders' Worldview. New York: Cambridge University Press, 2005: 3; Sekora, J. Luxury: The Concept in Western Thought, Eden to Smollett. Baltimore, MD: Johns Hopkins University Press, 1977: 32.

39 Паунд также указывает на влияние, оказываемое высоким уровнем произведений искусства на благосостояние страны и города: «Стоимость недвижимости, даже в Ньюарке, Нью-Джерси, пошла бы вверх, если бы Ньюарк был способен производить живопись, литературу или драматургию». Pound, Е. Literary Essays of Ezra Pound. New York: New Directions, 1968: 222.

40 Pound, E. How to Read. London: D. Harmsworth, 1931: 18. 
Здоровая цивилизация, как её понимает Паунд, укоренена в идее плодородия, природного избытка, естественного - а потому вечного порядка: «КРЕДИТ основан в пределе своем на ИЗОБИЛИИ ПРИРОДЫ, на растущей траве, которая питает живых овец» ${ }^{41}$. Примером практического воплощения принципа изобилия в исторической реальности для Паунда был сиенский банк Монте дей Паски («Этот чертовски славный банк в Сиене!»), кредитная политика которого опиралась на ежегодный прирост поголовья скота ${ }^{42}$. Поиск теоретических оснований естественного порядка приводит Паунда ко взглядам экономиста Сильвио Гезеллля, чью работу «Естественный экономический порядок» 1906 г. поэт внимательно изучил, заинтересовавшись идеей «портящихся денег» ${ }^{43}$. Гезеллль опирался в своих взглядах на Прудона, указывавшего на то, что в действительности продукция, а не деньги являются источником благосостояния. Однако у продукции есть естественное свойство портиться, постепенно исчезать. В то же время, деньги оказываются лишенными этого свойства, и в этом смысле - оторванными от мира реального благосостояния. Поэтому деньги необходимо принудительно наделить этим свойством: «Пусть их атакует моль и ржавчина, пусть они разлагаются, пусть утекают... тогда, и только тогда мы сможем сказать, что деньги и вещи находятся в одинаковом положении и совершенно эквивалентны друг другу - как того и хотел от них Прудон $\gg^{44}$. Деньги по Гезелллю должны со временем портиться - вместо того, чтобы приносить прибыль, они должны постепенно утрачивать свою ценность. Другими словами, речь шла о налоге на деньги. Этот налог (в виде марок, указывающих на уменьшение стоимости денежных знаков), должен был стимулировать собственников возвращать деньги в производительный оборот.

Денежные знаки - изобретение человека, которое не может иметь свойства, присущие природным объектам. Даже золото, природный материал, не даст урожая, если его посадить в землю. Однако «восхищенный блеском металла, человек превратил его в цепи. Тогда он изобрел нечто, противное природе, ложное воспроизводство в мире минералов

41 Pound, E. Selected Prose. London: Faber and Faber, 1973: 240.

42 См. о нем канто XLII. Паунд Э. Кантос. С. 195-200.

43 Критику экономических взглядов Паунда см. напр. в Lanteri, A. "Douglas, Gesell and the Economic Ethics of Ezra Pound." The History of Economic Ideas 19:1 (January 2011): 147-166.

44 Gesell, S. The Natural Economic Order. London: Peter Owen Ltd., 1958: 33. 
тех законов, которые свойственны только животным и растениям» ${ }^{45}$. Речь идет о возможности получать деньги из денег - ростовщичестве, приносящем невозможные в природе плоды. Золото неспособно порождать золото, и потому банковский процент, практика ростовщичества, usura, есть социальная форма противоестественных, перверсивных отношений. Торговые операции и ростовщичество, таким образом, противостоят производству, прежде всего - сельскохозяйственному, не только в экономическом смысле, но и в отношении своего влияния на человека. В этом смысле «Джон Тэйлор, работавший в полях вместе со своими рабами, может воплощать в себе республиканские ценности», но уже фигура Франклина у Паунда и других последователей Джефферсона вызывает подозрения в силу ее тесной связи исключительно со сферой коммерции и полного отрыва от аграрного мира ${ }^{46}$.

Тем более негативно Паунд, как и все иные радикальные республиканцы, относился к Александру Гамильтону, для которого знаковой фигурой был не земледелец, но торговец, отвечавший тому образу рыночных отношений, который Гамильтон хотел воплотить в жизнь в США, в значительной степени скопировав его с английского образца $^{47}$. В отличие от Гамильтона и его последователей, ни Муссолини, ни Джефферсон не попали под магическое обаяние денег и «царства количества»: «Если вы ищете узы симпатии между Т.Д. и Дуче, для начала примите во внимание, что они оба ненавидят машины или во всяком случае идею порабощения людей и превращения их в ЕДИНИЦЫ, единицы производства, стирания отдельной личности, сведения ее к мешанине» ${ }^{48}$. Другими словами, Муссолини, по мнению Паунда, наряду с Джефферсоном сохранял интерес к конкретному человеку, его индивидуальной духовной жизни. В этом конкретном контексте поэт совсем не против обратиться и к христианской системе ценностей в той мере, в которой она наследует античным установкам: «Ростовщичество и содомию Церковь отправляет вместе в один круг ада, как схожие по одной причине, а именно потому что они вместе противны естественному возрастанию» ${ }^{49}$. Здесь Паунд, безусловно, отсылает

45 Pound, E. Selected Prose: 316.

46 Marsh, A. Money and Modernity: 15.

47 Elkins, S., McKitrick, E. The Age of Federalism: The Early American Republic, 1788-1800. New York: Oxford University Press, 1993: 111.

48 Pound, E. Jefferson and/or Mussolini: 63.

49 Feldman, M. Ezra Pound's Fascist Propaganda, 1935-45: 43. 
к пассажу из «Политики» Аристотеля: «с полным основанием вызывает ненависть ростовщичество, так как оно делает сами денежные знаки предметом собственности, которые, таким образом, утрачивают то свое назначение, ради которого они были созданы: ведь они возникли ради меновой торговли, взимание же процентов ведет именно к росту денег ... как дети походят на своих родителей, так и проценты являются денежными знаками, происшедшими от денежных же знаков. Этот род наживы оказывается по преимуществу противным природе» ${ }^{50}$. Ростовщичество у Паунда оказывается средоточием разрушительных сил в обществе, именно оно «испортило республику» ${ }^{51}$, оно «рак этого мира, который может быть удален из жизни народов только хирургическим ножом Фашизма» ${ }^{52}$. Итальянский фашизм и отчасти - немецкий национал-социализм, таким образом, решают в современном мире сверхисторическую задачу борьбы с антиприродными и античеловеческими импульсами - задачу, которую сформулировали еще античные авторы. В фашизме Паунд считал эту задачу практически выполненной на национальном уровне: «Мертва, в 4-14 на Площади Дуомо в Милане, в году XII. Экономика Нехватки умерла» ${ }^{53}$. И потому для него «каждая реформа, каждое движение в сторону Справедливой Цены, в сторону контроля над рынком - дань уважения Муссолини и Гитлеру» ${ }^{54}$.

Паунд поднимает традиционную республиканскую тему личной ответственности за общее благо. История свидетельствует о том, что именно в силу инерции и безразличия населения свободу сменяет тирания и власть достается худшим (прежде всего - носителям частных экономических интересов). Цицерон, негодуя по поводу тех, кто предпочитает устраниться от решения вопросов публичных, пишет: «...как будто у людей честных, храбрых и наделенных большим мужеством, может быть какое-нибудь основание посвятить себя государственной деятельности, которое было бы более справедливым, чем желание не покоряться бесчестным людям и не позволять им раздирать государство

50 Аристотель. Сочинения: В 4 т. Т. 4. М.: Мысль, 1987. С. 395. Аристотель в Никомаховой этике указывает на ростовщичество как ремесло, недостойное свободных, сравнивая ростовщиков с содержателями публичных домов. Там же. C. 126 .

51 Marsh, A. John Kasper and Ezra Pound: 9.

52 Feldman, M. Ezra Pound's Fascist Propaganda, 1935-45: 48.

53 Pound, E. Jefferson and/or Mussolini: viii.

54 Rabaté, J.-M. Language, Sexuality, and Ideology in Ezra Pound's Cantos. Albany, NY: State University of New York Press, 1986: 206. 
на части» ${ }^{55}$. Спустя две тысячи лет Паунд вторит ему, противопоставляя итальянскую «некомпетентную интеллигенцию» ${ }^{56}$, «праздных болтунов и лентяев» ${ }^{57}$, «чувствительных добрых профессоров» ${ }^{58}$ фашистам под предводительством Муссолини. «Безразличные никогда не творили историю», - заявляет Паунд ${ }^{59}$. Он практически перефразирует Цицерона, который говорит о том, что «гражданин, который своим империем и страхом перед карой по закону заставляет всех людей делать то, к чему философы своей речью могут склонить разве только немногих, заслуживает предпочтения перед самими любителями наставлять, обсуждающими такие вопросы» ${ }^{60}$. Именно такой «фашистский идеал ОТВЕТСТВЕННОСТИ», с точки зрения Паунда, «значительно выше идеала свободы» ${ }^{61}$. Западная цивилизация как таковая «возникла из почвы и личной ответственности человека, который производит вещи с ее помощью» ${ }^{62}$.

Именно так Паунд предлагает понимать и правление Джефферсона - как реализацию этого идеала ответственности в конкретных исторических условиях: «Я не собираюсь ограничивать свой анализ тем, что Том Джефферсон сказал. Я не собираюсь ограничивать мой анализ тем, что Том Джефферсон рекомендовал в конкретное время в конкретном месте. Меня заботит то, что он в действительности делал, то, каким образом его разум реагировал как при столкновении с конкретной проблемой в конкретных географических условиях, так и при столкновении с вечной проблемой ИЗМЕНЕНИЙ» ${ }^{63}$. Так, например, «Все люди рождаются равными» - этот тезис позволил обывателю преодолеть вековое низкопоклонство перед наследственной британской и французской королевской властью. «Джон перестает

55 Цииерон. Диалоги. С. 10.

56 Pound, E. Jefferson and/or Mussolini: 24.

57 Ibid.: 56.

58 Ibid.: 59.

59 Ibid.: viii.

60 Цииерон. Диалоги. С. 8.

61 Feldman, M. Ezra Pound's Fascist Propaganda, 1935-45: 42. Свобода в этом контексте понимается, конечно, в либеральном ее значении. Себя Паунд, судя по всему, предпочитал считать одним из «ответственных» - Ноэль Сток вспоминал, что поэт «называл Кантос» «политическим оружием». Stock, N. Reading The Cantos: Study of Meaning in Ezra Pound. New York: Pantheon Books, 1966: 91.

62 Pound, E. Ezra Pound Speaking: Radio Speeches of World War II. Westport, CT: Greenwood Press, 1978: 176.

63 Pound, E. Jefferson and/or Mussolini: 11. 
лизать сапоги сквайра... идиотизм британского и французского дворов перестает гипнотизировать всех бедных болванов. Во всяком случае, что-то начинает меняться» ${ }^{64}$. Иначе говоря, истинное содержание действий Джефферсона (как и любого другого республиканца) не может быть выведено из совокупности статичных идей - его необходимо анализировать в контексте изелей. «Непостоянство», готовность идти на компромиссы - все это достоинства, а не недостатки: оппортунист «может быть ПРАВ, если у него есть определенные убеждения, которые он воплощает в конкретных условиях, или меняет и формирует эти условия в соответствии с ними. Осел из академии существует в вакууме с набором мертвых устойчивых идей» ${ }^{65}$. Паунд сравнивает поведение Джефферсона с «осознанным» поведением насекомых, которые, руководствуясь конкретной необходимостью, адаптируют свои инстинкты под изменяющиеся обстоятельства: «Когда человек обладает схожей полнотой знания, разума, проникающего в третье или четвертое измерение, способного справляться с НОВЫМИ обстоятельствами, мы называем его гением» ${ }^{66}$.

Даже аграрный идеал в действительности был только временной системой ориентаций - Джефферсон был «земледельцем» «...ДЛЯ своего времени и места, но он предчувствовал приближение промышленности» ${ }^{67}$. Он «был аграрием В колониях и в США СВОЕГО ВРЕМЕНИ» ${ }^{68}$. Эта гибкость Джефферсона проявлялась и в его теории смены поколений: «...Ни одно общество не может создать вечную конституцию или вечный закон. Земля всегда принадлежит живущему на ней поколению. [...] Каждая конституция, следовательно, и каждый закон естественным образом утрачивают свою силу по истечении 19 лет» ${ }^{69}$. $\mathrm{B}$ «Азбуке экономики» Паунд пишет, что он остается республиканцем в традиции Джефферсона, однако Джефферсона необходимо адаптировать к современному миру: «Вы можете упомянуть Конфуция и Ван Бюрена, но вы должны отличать 1820 от 1930, вы должны обновить
64 Ibid.: 21.
65 Ibid.: 17-18
66 Ibid.: 18-19.
67 Ibid.: 39.
68 Ibid.: 62 .

69 В определенном смысле законы по Джефферсону так же естественно портятся, как должны портиться деньги по Гезелллю. The Writings of Thomas Jefferson. Vol. V. New York: The Knickerbocker Press, 1895: 121. 
вашего Джефферсона ${ }^{70}$. Так, в свою очередь, и законы Муссолини это не законы «для идеальной республики, расположенной в платоническом раю», но именно то, что нужно и возможно «в Италии года VIII или IX Эры Фашизма» ${ }^{71}$.

Любой читатель, знакомый с флорентийской республиканской традицией, мгновенно вспоминает тезисы Макиавелли о том, что мудрый государь осознает необходимость соотносить свои действия с конкретными историческими условиями: «сохраняют благополучие те, чей образ действий отвечает особенностям времени, и утрачивают благополучие те, чей образ действий не отвечает своему времени» ${ }^{72}$. Джефферсона и Муссолини объединяет, прежде всего, это глубокое понимание необходимости достижения цели общего блага при помощи доступных средств: «НИКТО не сможет понять связь этих двух имен Джефферсон-Муссолини пока не представит себе такую перестановку: Что бы сделал Бенито Муссолини в американской глуши с 1770 по $1826 ?$ Что бы говорил и делал Том Джефферсон на узком средиземноморском полуострове, включающем Фоджию, Милан, Сиракузы, Флоренцию, с таким закостенелым консерватизмом, существование которого не может себе представить ни один американец без опыта путешествий?» ${ }^{73}$.

Именно через республиканское соотношение цели (общего блага) и средств, а не поверхностные политические интерпретации, Паунд трактует слова и поступки обоих правителей ${ }^{74}$. Чтобы увидеть единство Джефферсона и Муссолини, необходимо принять на веру их безусловную преданность этой цели общего блага: «Любое глубокое суждение о МУССОЛИНИ будет в определенной степени актом веры, оно будет зависеть от вашей веры в значение этого человека, вашей уверенности в понимании того, чего он хочет достичь» ${ }^{75}$. Точно так же,

70 Pound, E. The ABC of Economics. London: Faber and Faber, 1933: 53.

71 Pound, E. Jefferson and/or Mussolini: 57.

72 Макиавелли Н. Избранные сочинения. М.: Художественная литература, 1982. С. 373-374. Ср. у Паунда: «Возможно, что все другие революции совершались только после, то есть, существенно ПОСЛЕ изменения материальных условий, и что rivoluzione continua Муссолини является первой революцией, происходящей одновременно с изменением материальных основ жизни». Pound, E. Jefferson and/ or Mussolini: 127.

73 Ibid.: 23.

74 «Фашистская революция свершилась РАДИ сохранения определенных свобод и РАДИ поддержания определенного уровня культуры, определенных стандартов жизни...». Ibid.: 127.

75 Ibid.: 33 . 
если читатель изначально не верит в то, что Джефферсон беспокоился, прежде всего, о республике, он потеряется в кажущихся противоречиях его правления. И «...если вы не верите, что Муссолини движет огромная и глубокая “забота" или стремление к процветанию Италии, не бюрократической Италии или Италии как государственного механизма, сидящего на головах у людей, но Италии органичной, включающей в себя последнего пахаря и последнюю девушку в оливковых рощах, у вас возникнут значительные вопросы по поводу поверхностных не-джефферсоновских деталей» ${ }^{76}$. Именно эта либеральная привычка придираться к поверхностным деталям парализует современное население США и бросает республику к ногам ее врагов: «Англосаксу особенно трудно понять ясность латинского (sic) "Qui veut la fin veut les moyens". Кто ищет цели, ищет средства. Ленин как-то дал взвешенную оценку всем остальным русским партиям: Они очень умны, да, они способны на ВСЕ кроме действия» ${ }^{77}$.

Сама власть в руках республиканца приобретает черты искусства, а значит - и производства: «Чем больше изучаешь Миланскую Речь, тем больше она напоминает о Бранкузи, его каменных глыбах, не содержащих ошибки, с какого угла на них ни смотри» ${ }^{78}$. Такой правитель руководствуется импульсом к жизни и творению, который присущ любому здоровому организму. Муссолини он присущ в той же мере, что и, например, деду самого Паунда, о котором тот вспоминает: «...Мой дед построил железную дорогу, вероятно, не столько из желания сделать деньги или иллюзии, что так он заработает больше, чем каким-то другим способом, сколько из внутренней активности, из желания художника СДЕЛАТЬ что-то, из удовольствия от конструирования...» ${ }^{79}$.

И Джефферсон, и Муссолини были готовы действовать наперекор ожиданиям, авторитарно, без оглядки на мнение интеллектуалов. Джефферсон в ситуациях, которые того требовали, «не беспокоился о свободах ${ }^{80}$, и в целом «использовал юридические средства и юридические выражения как ИНСТРУМЕНТЫ» ${ }^{81}$. Еще в большей степени это касалось, конечно, Муссолини, положение которого осложнялось
76 Ibid.: 34 .
77 Ibid
78 Ibid.: viii.
79 Pound, E. The ABC of Economics: 37
80 Pound, E. Jefferson and/or Mussolini: 71.
81 Ibid.: 65 . 
еще одним обстоятельством - необходимостью создавать новую республику в условиях сопротивления старой культуры. Если американская государственность в самом своем основании имела республиканские идеалы, ситуация в Италии была иной: «Америке выпала удача начать с Сэма и Дж. Адамсов, Франклина и т.д. Освобождение и рождение происходили в рамках более-менее непрерывного процесса. У Италии было Рисорджименто, пробуждение от летаргии, частичное объединение, а потом сорок лет сна, следующее восстание от которого было делом, в основном, одного человека» ${ }^{82}$. Однако, как писал Макиавелли ровно об этом и применительно к Риму же: «...если Риму не повезло вначале, то ему повезло потом. Первые учреждения его были плохи, но не настолько, чтобы свернуть его с правильного пути, могущего привести к совершенству» ${ }^{83}$.

Применительно к обоим своим героям Паунд мог бы заимствовать латинскую цитату из «Государя»: "lustum enim est bellum quibus necessarium, et pia arma ibi nulla nisi in armis spes est". Ибо та война справедлива, которая необходима, и то оружие священно, на которое единственная надежда. Ни Джефферсон, «ни Муссолини не интересовались, в действительности, государственным аппаратом. Это не парадокс- они оба изобрели и использовали его, но они оба были значительно более заинтересованы в чем-то ином ${ }^{84}$. Общественное благо как единственно значимая цель определяет и оправдывает политику Муссолини и Джефферсона, именно она отличает их от тех, кто стремится к власти ради личной выгоды ${ }^{85}$. Критически отзываясь о Ницше, Паунд отмечает, что «воля к власти» - вульгарная, вредная концепция: «Великий человек исполнен совершенно иной страстью, волей к порядку» ${ }^{86}$.

В письме к американскому экономисту Хьюго Фэку Паунд говорит об «ИДЕАЛЕ, содержащемся в Фашизме БУДУЩЕГО, где государство сможет РАССЛАБИТЬСЯ и ничего не делать», который наступит в тот момент, когда будет достигнута автаркия ${ }^{87}$. По большому счету, Паунд

82 Ibid.: 89.

83 Макиавелли Н. Избранные сочинения. С. 386.

84 Pound, E. Jefferson and/or Mussolini: 61.

85 См. по этому поводу, напр. главу VIII «Государя»: «О тех, кто приобретает власть злодеяниями».

86 Pound, E. Jefferson and/or Mussolini: 99. Этим же тезисом Паунд завершает свое «сравнительное жизнеописание»: «...Дуче стоит плечом к плечу не с деспотами и властолюбцами, но с приверженцами ПОРЯДКА». Ibid.: 128.

87 Ezra Pound's Economic Correspondence, 1933-1940. Gainesville, FL: University of Florida Press, 2001: 169-170. 
говорит о том, что само государство существует только в силу неспособности народа самостоятельно поддерживать это состояние республиканской автаркии ${ }^{88}$. Правитель взваливает на себя бремя, значение которого могут оценить лишь немногие, в чем, собственно, и состоит весь пафос республиканской теории власти: «ЕСЛИ, когда и в каждом случае, когда индивид или отрасль может справиться и справляется со своим делом самостоятельно, фашистское государство ЖЕЛАЕТ, чтобы отрасль или индивид так и СДЕЛАЛИ, и только в случаях полного идиотизма, некомпетентности или обычной жадности собаки на сене государство вмешивается, чтобы защитить неорганизованный НАРОД; население; вас, меня и того парня» ${ }^{89}$.

Подобное отношение к государственной власти - как к досадной необходимости - было близко и понятно всем тем, кто относил себя в США к истинным консерваторам, не утратившим исторической памяти о дореволюционном периоде, для которого было характерно минимальное вмешательство власти в повседневную жизнь населения ${ }^{90}$. Усиление государства не вызывало энтузиазма у республиканцев - оно свидетельствовало о деградации общества. Однако в то же время, парадоксальным образом, только удержание и усиление этой власти в руках истинных патриотов могло спасти это общество от окончательной гибели. Именно в этом и состояла вся суть правления Муссолини для Паунда - обратить процесс инерции вспять, «осушить болота» в Италии, которая впоследствии могла бы стать примером и для США. Итальянский фашизм для Паунда был обещанием новой зари Американской Республики.

88 Ср. у Макиавелли: «Из всего вышесказанного следует, что в развращенных городах сохранить республику или же создать ее - дело трудное, а то и совсем невозможное. А ежели все-таки ее в них пришлось бы создавать или поддерживать, то тогда необходимо было бы ввести в ней режим скорее монархический, нежели демократический, с тем чтобы те самые люди, которые по причине их наглости не могут быть исправлены законами, в какой-то мере обуздывались властью как бы царской». Макиавелли Н. Избранные сочинения. С. 420.

89 Pound, E. Jefferson and/or Mussolini: 69.

90 Так, например, на пороге Войны за независимость в Массачусетсе на 300000 жителей этой колонии приходилось менее тысячи должностных лиц, из которых только 6 человек выполняли свои функции на условиях полной занятости. Джефферсон писал: «Я убежден, что общества (как у индейцев), живущие без государства, в бесконечно большей степени счастливы, чем те, что живут под властью европейских государств». Thomas Jefferson: Writings. New York: The Library of America, 1984: 880. 
Один из исследователей политических симпатий Паунда, Алек Марш, справедливо замечает, что Паунд, соединяющий в своем мировоззрении конфуцианство, фашизм, джефферсонианство, оказал хотя и неочевидное, но реальное влияние на становление современных форм правого радикализма, и в частности - на возникновение Чайной партии ${ }^{91}$. Однако этот тезис хотя и верен сам по себе, в то же время преуменьшает масштаб феномена 92 . Эзра Паунд не был просто гениальным эксцентриком, в силу личного таланта оказавшимся способным донести свои взгляды до читателя. Он являлся обладателем вытесненного на обочину американской политической жизни стиля политического мышления, который можно назвать радикальным республиканизмом. В этом отношении Паунд интересен не как самостоятельный эклектичный теоретик, но прежде всего - как яркий представитель и своего рода проводник в мир американского консервативного подполья, история которого насчитывает почти 250 лет (как минимум - с периода дебатов о Конституции США). Весь корпус поздних работ Паунда можно в определенном смысле рассматривать как огромный поэтический комментарий к республиканскому наследию. К Паунду абсолютно применимо замечание Клинтона Росситера по поводу событий 1776 года: «...какими бы радикальными ни казались принципы Революции всему остальному миру, в сознании колонистов они были насквозь охранительными и уважительными к прошлому» ${ }^{93}$. Паунду были свойственны черты, характерные практически для всех обитателей этого республиканского андеграунда (в том числе - и современных), и прежде всего - интенсивно нарастающая радикализация взглядов в ответ на тотальный отказ со стороны истэблишмента всерьез воспринимать систему ценностей, занимающую совершенно законное место в истории и культуре США. Собственно говоря, для Паунда и многих других, значительно менее

91 Marsh, A. John Kasper and Ezra Pound: xiv.

92 Это не умаляет, однако, достоинств работ Марша, в которых он анализирует взгляды Паунда в контексте американского популизма и исследует связи поэта с праворадикальными группами периода расовой интеграции в США. Тем не менее, для Марша Паунд остается, прежде всего, поэтом-модернистом, имевшим неосторожность связать себя с неправильными людьми. Нам же представляется, что политические взгляды Паунда интересны ровно в той мере, в которой они принадлежат республиканской традиции, маргинальный статус которой с неизбежностью притягивал в ее орбиту значительное число сомнительных персонажей.

93 Rossiter, C. Seedtime of the Republic. New York: Hartcourt, Brace and World Inc., 1953: 448. 
известных американских интеллектуалов, именно эта вытесненная традиция, восходящая к Томасу Джефферсону и далее - к античным авторам, была и остается истинной основой американской цивилизации.

\section{ЛИТЕРАТУРА}

Аристотель. Сочинения: В 4 т. Т.4. М.: Мысль, 1987.

Бейлин Б. Идеологические истоки Американской революции. М.: Новое издательство, 2010.

Джеффферсон Т. Заметки о штате Виргиния. Л.: Наука, 1990.

Катон М.П. Земледелие. М.-Л.: Издательство Академии Наук СССР, 1950. 1982.

Макиавелли Н. Избранные сочинения. М.: Художественная литература,

Паунд Э. Кантос. СПб.: Наука, 2018.

Цицерон. Диалоги: О государстве; О законах. М.: Наука, 1966.

Цицерон. О старости. О дружбе. Об обязанностях. М.: Наука, 1974.

\section{REFERENCES}

Aristotle. Sochinenija: 4 vols. [Works: in 4 vols.] Vol. 4. Moscow: Mysl' Publ., 1987. (In Russ.)

Bejlin, B. Ideologicheskie istoki Amerikanskoj revoljucii. [The Ideological Origins of the American Revolution] Moscow: Novoe izdatel'stvo Publ., 2010. (In Russ.)

Cato, Marus Portius. Zemledelie. [On Farming] Moscow-Leningrad: Izdatel'stvo Akademii Nauk SSSR Publ., 1950. (In Russ.)

Cicero. Dialogi: O gosudarstve; O zakonakh. [Dialogues: On State; On Laws] Moscow: Nauka Publ., 1966. (In Russ.)

Cicero. O starosti. O druzhbe. Ob objazannostjah. [On Old Age. On Friendship. On Duties] Moscow: Nauka Publ., 1974. (In Russ.)

Colbourn, T. The Lamp of Experience: Whig History and the Intellectual Origins of the American Revolution. Chapel Hill, NC: University of North Carolina Press, 1965.

Cornell, S. The Other Founders. Anti-Federalism and the Dissenting Tradition in America, 1788-1828. Chapel Hill, NC: University of North Carolina Press, 1999.

Dickinson, J. An Essay on the Constitutional Power of Great-Britain over the Colonies in America. Philadelphia, PA: W. Thomas Bradford, 1774.

Elkins, S., McKitrick, E. The Age of Federalism: The Early American Republic, 1788-1800. New York: Oxford University Press, 1993.

Ezra Pound's Chinese Friends. Oxford: Oxford University Press, 2008.

Ezra Pound's Economic Correspondence, 1933-1940. Gainesville, FL: University of Florida Press, 2001. 
Feldman, M. Ezra Pound's Fascist Propaganda, 1935-45. Basingstoke: Palgrave Macmillan, 2013.

Fox-Genovese, E. The Origins of Physiocracy. Ithaca and London: Cornell University Press, 1976.

Fox-Genovese, E., Genovese, E. The Mind of the Master Class: History and Faith in the Southern Slaveholders' Worldview. New York: Cambridge University Press, 2005.

Gesell, S. The Natural Economic Order. London: Peter Owen Ltd., 1958.

Hofstadter, R. The Age of Reform: From Bryan to F.D.R. New York: Vintage Books, 1955.

I Cease Not to Yowl: Ezra Pound's Letters to Olivia Rossetti Agresti. Urbana, IL: University of Illinois Press, 1998.

Jefferson, T. Zametki o shtate Virginija. [Notes on the State of Virginia] Leningrad: Nauka Publ., 1990. (In Russ.)

Lanteri, A. "Douglas, Gesell and the Economic Ethics of Ezra Pound." The History of Economic Ideas 19:1 (January 2011): 147-166.

Makiavelli N. Izbrannye sochinenija. [Selected Works] Moscow: Hudozhestvennaja literatura Publ., 1982. (In Russ.)

Marsh, A. John Kasper and Ezra Pound. London; New York: Bloomsbury Academic, 2015.

Marsh, A. Money and Modernity: Pound, Williams, and the Spirit of Jefferson. Tuscaloosa, AL: The University of Alabama Press, 1998.

Marx, L. The Machine in the Garden: Technology and the Pastoral Ideal in America. New York: Oxford University Press, 1967.

McDonald, F. The Presidency of Thomas Jefferson. Lawrence, KS: University Press of Kansas, 1976.

Pocock, J.G.A. The Machiavellian Moment. Princeton:, NJ: Princeton University Press, 1975.

Pound, E. The ABC of Economics. London: Faber and Faber, 1933.

Pound, E. Ezra Pound Speaking: Radio Speeches of World War II. Westport, CT: Greenwood Press, 1978.

Pound, E. How to Read. London: D. Harmsworth, 1931.

Pound, E. Jefferson and/or Mussolini. London: Stanley Nott Ltd., 1935.

Pound, E. Kantos. [The Cantos] Saint-Petersburg: Nauka Publ., 2018. (In Russ.)

Pound, E. Literary Essays of Ezra Pound. New York: New Directions, 1968. 1958.

Pound, E. Pavannes \& Divagations. New York: New Directions Publishing,

Pound, E. Selected Prose. London: Faber and Faber, 1973.

Rabaté, J.-M. Language, Sexuality, and Ideology in Ezra Pound's Cantos. Albany, NY: State University of New York Press, 1986.

Redman, T. Ezra Pound and Italian Fascism. Cambridge: Cambridge University Press, 1991. 
Robbins, C. The Eighteenth-Century Commonwealthman. New York: Atheneum, 1968.

Rossiter, C. Seedtime of the Republic. New York: Hartcourt, Brace and World, Inc., 1953.

Sekora, J. Luxury: The Concept in Western Thought, Eden to Smollett. Baltimore, MD: Johns Hopkins University Press, 1977.

Selected Political Essays of James Wilson. New York: Alfred Knopf, 1930.

Stock, N. Reading The Cantos: A Study of Meaning in Ezra Pound. New York: Pantheon Books, 1966.

Surette, L. Dreams of a Totalitarian Utopia: Literary Modernism and Politics. London: McGill-Queen's University Press, 2011.

Terrell, C.F. A Companion to The Cantos of Ezra Pound. Vol. II. Berkeley, CA: University of California Press, 1984.

Thomas Jefferson: Writings. New York: The Library of America, 1984.

Wood, G. "Conspiracy and the Paranoid Style: Causality and Deceit in the Eighteenth Century." The William and Mary Quarterly 39:3 (July, 1982): 401-444.

Wood, G. The Radicalism of the American Revolution. New York: Vintage Books, 1991.

The Works of John Adams. Vol. X. Boston, MA: Little, Brown and Company, 1856.

The Writings of Thomas Jefferson. Vol. V. New York: The Knickerbocker Press, 1895. 